The pool in the harbour known as the Iron Pot, where fishing-boats and small steamers hitherto lay, is now dry land. According to the report of the Governor-General, the bed of the harbour has been raised in places by 18 feet. It seems clear that the rise of the land was not abrupt, for steamers left the harbour and proceeded to sea " on account of the anchorage shallowing rapidly".

For many years, slight earthquakes have been frequent in the Napier district. In the list of New Zealand earthquakes from 1848 to 1890 drawn up by the late Mr. G. Hogben, at least 27 earthquakes had their origins in this zone.

Though the stronger earthquakes of New Zealand can scarcely be ranked with the greatest of some other lands, they have all been accompanied by notable displacements of the earth's crust. In 1826, a cove in the South Island about 80 miles north of Dusky Bay was converted from a safe anchorage for sealing vessels into dry land. The earthquakes of 1848 visited the northern part of the South Island. A great rent was then formed in the mountain chain running south-south-west from Cloudy Bay, and was traced for a distance of
60 miles. During the Wellington earthquake of 1855, a tract of land at the southern end of the North Island measuring 4600 square miles was uplifted from one to nine feet. The fault along which the greatest movement occurred runs along the eastern flank of the Remutaka range, and the nearly vertical scarp was traced for a distance of about 90 miles. Lastly, with the earthquake of 1929, which occurred in the north-west portion of the South Island, the ground on the east side of the White Creek fault was shown, by the renewed levelling of the district, to have risen at one point by $16 \mathrm{ft} .1 \mathrm{in}$.

The investigation of the recent earthquake by the competent seismologists of New Zealand and the re-levelling of its central area can scarcely fail to add greatly to our knowledge. One of the most interesting points to be determined is the connexion of the earthquake with the fault or system of faults that was in action in 1855 ; for though 30 miles or more to the north-north-east of the end of the fault-scarp of that year, the meizoseismal area seems to lie along, or not far from, its line of continuation.

\title{
Obituary.
}

Mr. A. B. BASSET, F.R.S.

ALFRED BARNARD BASSET was born on I July 25, 1854. He was educated at Trinity College, Cambridge, and graduated in 1877 as 13 th wrangler, a position which could scarcely have represented his real mathematical attainments. He was called to the Bar at Lincoln's Inn in 1879, but not being under the necessity of adopting a profession, he soon abandoned the law, and, apart from the duties of his private station, devoted himself mainly to mathematical research.

From 1883 onwards Basset produced a succession of papers on applied mathematics, mainly on subjects suggested by current discussions. The ' classical ' hydrodynamics had at that time a great fascination for a number of rising mathematicians, and Basset's own contributions in this kind to the Proceedings of the Cambridge Philosophical Society, the London Mathematical Society, and the Philosophical Transactions were of distinct merit. Among the numerous subjects which he treated we may mention the equilibrium of revolving fluids, and the theorems of Dirichlet and Dedekind, the interest in which had been revived by Bryan, Greenhill, and Love. At a later stage he attacked the theory of elastic plates and shells, which was then a matter of controversy, and was led to recognise independently the true explanation of a rather serious difficulty. Mention should also be made of his work on viscosity, and in particular on Boussinesq's problem of the variable slow motion of a sphere in a viscous fluid. These are only a few items out of the long list which appears in the Royal Society's catalogue.

Basset's work was distinguished throughout by a remarkable command of analytical methods. As an example, it may be noted that he was an expert in the use of Bessel functions, and discovered new results in this connexion, at a time when the theory was only beginning to be familiar to English applied mathematicians. He was elected a fellow of the Royal Society in 1889, and was vice-president of the Mathematical Society in 1892-93.

Basset was also the author of several able treatises. A work on hydrodynamics, in which he incorporated much of his original work, was published in 1888, and did much to promote the interest in the subject. This was followed in 1892 by a treatise on physical optics, another of his favourite subjects, to which he devoted immense pains, but which scarcely met with the recognition which it undoubtedly deserved.

At a later period, Basset turned his attention to pure mathematics, and produced two text-books, on cubic and quartic curves, and on solid geometry. But his interest in scientific matters, and his relations with mathematical contemporaries, seem gradually to have faded, partly no doubt owing to failing health, and he lived in great retirement at his seat in Berkshire. He died on Dec. 5, at the age of seventy-six years.

H. L.

\section{Dr. F. M. TURNer.}

Dr. F. M. Turner died unexpectedly on Jan. 17 at the age of sixty-four years, after a surgical operation. Educated at Cambridge and Guy's Hospital, he was for thirty-four years the loved and respected superintendent of the South-Eastern Fever Hospital at New Cross. He was an acute student of infectious diseases, and published notable work on return. cases of scarlet fever in 1906 and on the relation between vaccination and smallpox in Biometrika in 1906 and 1907.

Dr. Turner was a man of insatiable curiosity and had wide interests outside his immediate professional concerns, especially in fresh-water biology and the keeping of aquaria, in which he had a happy

$$
\text { No. 3198, VoL. 127] }
$$


knack. He read widely and always maintained a keen interest in fresh developments of biology. $\mathrm{He}$ took a large part in the investigation of the inheritance of sinistrality in Limnae peregra with Boycott, Diver, and Garstang, recently published in the Phil. Trans., and incidentally made a number of valuable measurements of the factors which influence the rate of growth of water snails. 'Semper's law' particularly attracted him, and he succeeded in showing fairly conclusively that the larger size of individuals reared in larger volumes of water is due to the greater supply of food. He also made a number of original observations on the kinds of algæ actually eaten by snails, and of their preferences and dislikes for different species. Some of his results are published in the Naturalist (p. 231 ; 1926) and the Essex Naturalist (p. 48 ; 1927), but many of his problems were waiting for the further experiments which he had planned to make when he retired this next summer.

WE regret to announce the following deaths:

Mr. J. D. H. Dickson, senior fellow of Peterhouse and author of numerous papers on thermodynamics and thermoelectricity, on Feb. 6, aged eighty-one years.

Mr. D. T. Jones, C.B.E., chairman of the Fishery Board for Scotiand, on Feb. 4, aged sixty-five years.

Dr. C. Krumwiede, professor of hygiene and bacteriology at New York University, assistant director of the research laboratory of the Health Department of New York and past president of the Society of American Bacteriologists, on Dec, 28, aged fifty-one years.

Dr. Albert Schammelhout, secretary of the International Pharmaceutical Federation and an honorary member of the Pharmaceutical Society of Great Britain, on Jan. 20, aged sixty years.

\section{News and Views.}

Early this year we had the pleasure of offering congratulations on behalf of scientific workers generally to Sir Ernest Rutherford on the barony conferred on him by H.M. the King, announced in the New Year's Honours List (NATURE, Jan. 10, p. 65). A further proof of the world-wide recognition of his brilliant achievements is the award, which we are glad to announce, of the Echegaray Medal of the Royal Academy of Sciences of Madrid. This medal was founded by the Academy in honour of Señor $D$. José Echegaray, its president from 1901 until 1916, and is awarded triennially to any person, Spaniard or foreigner, who shall, in the opinion of the Academy, have distinguished himself to an eninent degree in one or other of the branches of science for the promotion of which the Academy exists. Previous recipients of the medal are: Señor José Echegaray (1907), Señor Eduardo Saavedra (1910), Prince Albert I. of Monaco (1913), Señor Leonardo Torres Quevedo (1916), Prof. Svante Arrhenius (1919), Prof. Santiago Ramón y Cajal (1922).

ON Feb. 15 occurs the centenary of the death of the famous mechanician and engineer, Henry Maudslay, who was not only the founder of one of the most historic engineering firms of London but also was the originator of important advances in machine tools and engine construction. He was the first to construct screw cutting lathes in which the slide rest is moved along the bed by means of a leading screw driven by change wheels; and it was from his interchangeable system of serew threads that Whitworth afterwards developed the well-known Whitworth system. Born in Woolwieh in 1771, the son of a soldier who had become a carpenter in Woolwich Arsenal, Maudslay began work in the Arsenal at twelve years of age and by eighteen had acquired such extraordinary mechanical skill that Bramah employed him on the construction of his locks. Later on, at the age of twenty-six, Maudslay set up in business for himself in Wells Street, and in 1810 founded the works in the Westminster Bridge Road where, for nearly a century, marine engines were constructed for the Navy. He was the maker of the famous block-making machinery devised by Brunel for Portsmouth Dockyard. And among his workmen were Clements, who afterwards constructed Babbage's calculating machine, Nasmyth, the inventor of the steam hammer, and Whitworth. Into all his work, Maudslay introduced mathematical accuracy, while his constiuctions were all known for their beauty of proportion. The business he founded was carried on until 1905. On his death, Maudslay, at his own desire, was buried in Woolwich churchyard, where a monument recalls his merits as an engineer and a man.

The Royal Commission on Transport, in its final report on the co-ordination and development of transport in Great Britain (see also p. 225), considers that of the two main causes of the present difficulties of railways, the long-continued depression in trade, especially in the 'heavy' industries, is the more important, though road competition will be a more permanent adverse factor. To meet such competition, a thorough overhauling of railway schedules, with speeding up of services and improved conveniences, including the removal of irritating conditions, revision of fares, and increased seating accommodation on main line trains, are recommended. In regard to grouping under the Railways Act, the report recommends that each company should confine its attention to the needs of its particular area; that joint lines should be merged and the traffic pooled at points served by two or more railways. Electrification of all suburban services where there is intensive passenger traffic, the closing of little-used and unremunerative branch lines, and progress in the use of larger waggons and of containers are other recommenditions. In regard to road trans. port, expenditure on by-pass roads but not on new arterial roads is recommended; and the activities of the Ministry of Transport stould be concentrated on the complete reconstruction of many existing roads, the widening of roads, improvement of road junctions and lines of sight, strengthening of weak bridges, freeing of toll roads and bridges, and the progressive reconstruction of built-up areas.

$$
\text { No. 3198, VoL. } 127\rceil
$$

